\title{
Major elements and lithostratigraphic study of the contact rocks of the Togo and the Dahomeyan formations in Ghana
}

\author{
Mawutorli Nyarku ${ }^{1 *}$, Samuel Yao Ganyaglo ${ }^{1}$, Eric Tetteh Glover $^{1}$, Yaw Serfor-Armah ${ }^{2}$ \\ ${ }^{1}$ National Nuclear Research Institute, Ghana Atomic Energy Commission, Accra, Ghana; \\ *Corresponding Author: mawuutorli@yahoo.com \\ ${ }^{2}$ Graduate School of Nuclear and Allied Sciences, University of Ghana, Accra, Ghana.
}

Received 4 April 2011; revised 26 April 2011; accepted 30 April 2011.

\section{ABSTRACT}

The thrust contact between the Togo and the Dahomeyan formations in Ghana is a lithotectonic boundary that exists between two major Precambrian formations which are of importance to geologists owing to the fact that Precambrian rocks in Ghana host almost all economic minerals and metals. The lithostratigraphy of the Togo-Dahomyan thrust contact rocks from a borehole in Kwabenya near Accra (the Capital of Ghana) has been studied and major crustal chemical elements assayed using Instrumental Neutron Activation Analysis (INAA) techniques. The results have revealed elemental compositions and the mineralogical make up of the lithostratigraphic units of these contact rocks and the general geology of the Togo and the Dahomeyan formations. The profile shows a thrust contact that exists between the Togo formations which are underlying the Dhomeyan formations. The Togo formations here are made mainly of quartzite in fresh schist and the Dahomeyan made of gneisses. In between these two major geologic formations are the rocks of the contact which are intercalation of quartzite and schist. The rocks are felsic with an average felsic index (F) of 85.74 and feldspar rich with $\mathrm{K}$-(orthoclase) feldspars dominating the Dahomeyan rocks. Iron and titanium oxides are depleted with depth from $52 \mathrm{~m}$ depth below surface downward and potassium oxide was enriched with depth from $\mathbf{4 2} \mathrm{m}$ below surface downward. Major mineral forming elements such as aluminum and calcium had varied levels in the Togo and in the Dahomeyan rocks.

Keywords: Dahomeyan; Togo; Contact Rocks;
Elemental; Concentrations; INAA; Ghana

\section{INTRODUCTION}

Thrust contact of the Togo and the Dahomeyan formations underlie some suburbs of Accra such as Kwabenya and Achimota. The geology of the Togo and Dahomeyan formations and their contact are well described by Blay and Kesse [1,2]. Rocks of these two formations and their thrust contact are important owing to the fact that the Togo and the Dahomeyan formations are among Precambrian rocks in Ghana which happened to host majority of the economic minerals and metals. The lithologic successions of these two formations are known to be complex. The Togo has been classified into three stratigraphic divisions namely: Basic, Arenaceous and Argillaceous groups while the Dahomeyan formations have been classified into an order of Acidic Dahomeyan, Alkalic gneiss, Basic intrusives and the Metabasics respectively with the first in each case being the youngest and at the top of the lithosuccession. The Togo formations are Upper Precambrian while the Dahomeyan formations are Middle to Late Precambrian [3,4]. The Togo formations are deformed thrusted supracrustal rocks and trend northeast-southwest. The Dahomeyan formations are belts with the same northeast-southwest trending east of the Togo, they are highly metamorphosed and are associated with much thermotectonic activities. The Dahomeyan formations are found in the easternmost part of Ghana. Mineral and for that matter elemental composition of these contact rocks have always been of interest to geologists, as this has helped to establish origin, evolution and the geology of the contact. Since quantity of chemical elements in a mineral is what determines the mineral type and the mineral name, elemental data on rocks and minerals of the thrust contact of the Togo and the Dahomeyan formations is needful for the proper 
characterization of the geology of this contact. In this research, lithostratigraphic profile of rocks of the Togo-Dahomeyan contact from a borehole drilled on the site of the Ghana Atomic Energy Commission in Kwabenya (shown on the map of Figure 1), one of the terranes of the Togo-Dahomeyan contact was logged and studied. The study was in two aspects-assay of major crustal and mineral forming elements using Instrumental Neutron Activation techniques, and the study of the minerals profile of the bedrock which happens to be within a site that has been earmarked for a radioactive waste disposal facility. The logged cuttings of the borehole were examined to reveal the lithostratigraphic profile of the rocks and then their elemental composition assayed. Results of this work have revealed mineralogical and elemental make up of lithostratigraphic units of the borehole; and the general geology of the Togo-Dahomeyan contact at the area. These results have been used to characterize the site earmarked for the radioactive waste disposal facility.

\section{EXPERIMENTAL METHODS}

\subsection{Sample Logging and Preparation}

A quantity of about $3 \mathrm{~kg}$ of cuttings and chips was collected from the borehole into polyethylene packs after every $3 \mathrm{~m}$ depth was drilled starting from the depth of $5.5 \mathrm{~m}$ which is the depth of unconsolidated lateritic soil. Twenty two (22) samples were collected from the borehole for up to the $72 \mathrm{~m}$ depth below surface. The samples were coded and pre-fixed with BF followed by the depth in meters at which the sample was taken. For example a sample with code BF12 is one taken from the depth $12 \mathrm{~m}$ below the surface level in the borehole. Each sample was examined to identify its rock composition before being air-dried. After air-drying, each sample was disaggregated and pulverized into powder using the agate mortar (Vibratory Disc Mill RS100) to ensure homogeneity and also to form a composite sample. Two replica representative samples that weighed $100 \mathrm{mg}$ each were then taken from every composite sample and wrapped in thin polyethylene papers. Replica samples of $100 \mathrm{mg}$ each were also prepared for certified rock reference materials (CRM's) GBW07106 and GBW07107. The samples and standards were packed into $7 \mathrm{~mL}$ plastic vials and heat-sealed. For the purpose of results validation, single element gold standard solution (SRM 3121) of concentration $10.00 \pm 0.03 \mu \mathrm{g} / \mathrm{g}$ was pipetted (using Eppendorf tip ejector pipette; Brinkmann Instruments, Inc. Westbury, New York) into a clean $1.5 \mathrm{~mL}$ polyethylene vial and weighed. Weight of the empty vial was zeroed (pre-weighed) in order to obtain the weight of the

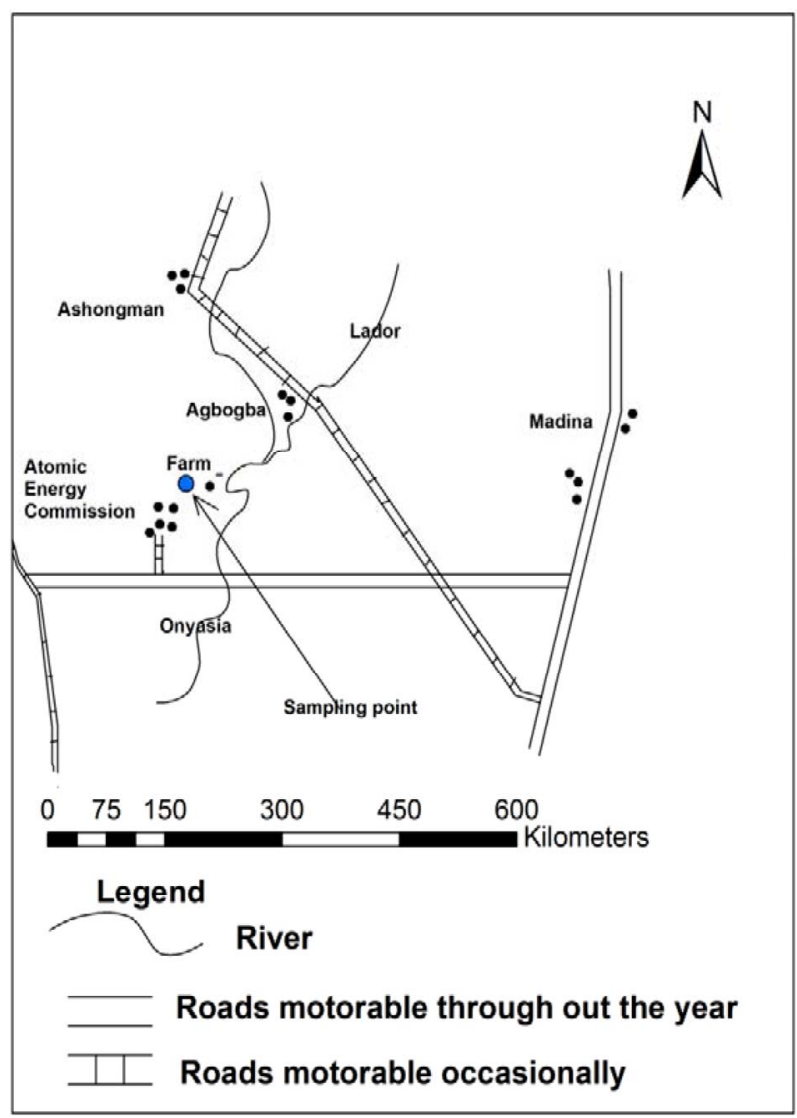

Figure 1. Location map of sample collection and study area.

standard solution. Ground sucrose (from SIGMA-ALDRICH, Inc. 3050 Spruce Street St Louis MO 63103 US) was added to the solution-in order to solidify it and then allowed to dry at room temperature before being heat-sealed and placed into a $7 \mathrm{~mL}$ vial for irradiation.

\subsection{Irradiation and Counting of Samples}

Samples and their standards were irradiated in order for the various elements of interest to be activated and subsequently assayed. The samples were divided into two groups to enable all elements of interest to be determined. One group was used for the determination of medium and long lived nuclides and the other group for the determination of short-lived nuclides. Irradiation of samples and standards was done using the pneumatic rabbit system of the Ghana Research Reactor-1 (GHAAR-1) operating at half-full power of $15 \mathrm{KW}$ (thermal) and neutron flux of $5.0 \times 10^{11} \mathrm{n} / \mathrm{cm}^{2} \cdot \mathrm{s}$. Samples used for the determination of long and medium lived nuclides were irradiated for 1 hour. After their irradiation, the medium-lived samples were decayed for between 2 to 4 days before counting while the long-lived nuclides samples were decayed for between 4 to 8 weeks before counting. Samples used to assay short-lived nu- 
clides were irradiated for 10 seconds and counted immediately after irradiation. The PC-interfaced N-type HPGe (High Purity Germanium) gamma ray detector system was used for detection, counting and gamma spectra acquisition. The efficiency of the detector system was $25 \%$ relative to standard $2 " \times 2$ " $\mathrm{NaI}$ detector and it operated in a bias voltage (of $-3000 \mathrm{~V}$ ) with a FWHM (Full Width at Half Maximum) resolution of $1.8 \mathrm{keV}$ for ${ }^{60} \mathrm{Co}$ gamma ray energy of $1332 \mathrm{keV}$. Spectra intensities of the samples and standards obtained by means of a MCA (Multi-Channel Analyser) card (ORTEC, 2002) that is coupled to the PC were used along with the certificate of the CRM's used to calculate the concentrations of both oxides and elements.

\section{RESULTS AND DISCUSSIONS}

Drilled cuttings collected from different depths of the borehole examined to determine the strategraphic profile of the rocks reveal a profile shown in Figure 2. Rocks of the borehole were predominantly schist, gneiss, quartzite, phyllite. The profile of the borehole confirms earlier works that have been done with respect to the sequence of rocks below and above the thrust contact that, rocks of the Togo are underlain by Dahomeyan formations [6]. Elemental assay results are captured in two tables: Table 1 for major oxides and Table 2 for major elements. Major oxides determined in this work were: $\mathrm{Al}_{2} \mathrm{O}_{3}, \mathrm{CaO}$, $\mathrm{Fe}_{2} \mathrm{O}_{3}, \mathrm{~K}_{2} \mathrm{O}, \mathrm{Na}_{2} \mathrm{O}$ and $\mathrm{TiO}_{2}$ (Table 1). The results show that the concentration by weight of these oxides was in the order: $\mathrm{TiO}_{2}>\mathrm{Al}_{2} \mathrm{O}_{3}>\mathrm{Na}_{2} \mathrm{O}>\mathrm{K}_{2} \mathrm{O}>\mathrm{CaO}>\mathrm{Fe}_{2} \mathrm{O}_{3}$; showing that, the rocks are $\mathrm{Fe}_{2} \mathrm{O}_{3}$, and $\mathrm{CaO}$ deficient. Felsic index $(F)$ is found by the ratio of $\left(\mathrm{Na}_{2} \mathrm{O}+\mathrm{K}_{2} \mathrm{O}\right) \mathrm{X}$ 100 and $\left(\mathrm{CaO}+\mathrm{Na}_{2} \mathrm{O}+\mathrm{K}_{2} \mathrm{O}\right)$ and mafic index $(\mathrm{M})$ is found by the ratio of $\left(\mathrm{FeO}+\mathrm{Fe}_{2} \mathrm{O}_{3}\right) \times 100$ and $(\mathrm{MgO}+$ $\mathrm{FeO}+\mathrm{Fe}_{2} \mathrm{O}_{3}$ ). Felsic index has been computed for these rocks.

Table 1. Concentrations of oxides.

\begin{tabular}{|c|c|c|c|c|c|c|c|}
\hline Sample Code & $\mathrm{Al}_{2} \mathrm{O}_{3}(\% w t)$ & $\mathrm{CaO}(\% w t)$ & $\mathrm{Fe}_{2} \mathrm{O}_{3}(\% w t)$ & $K_{2} O(\% w t)$ & $\mathrm{Na}_{2} \mathrm{O}(\% w t)$ & $\mathrm{TiO}_{2}(\mathrm{ppm})$ & Felsic Index \\
\hline BF9 & $23.79 \pm 0.10$ & $1.47 \pm 0.22$ & $0.91 \pm 0.09$ & $2.43 \pm 0.12$ & $6.49 \pm 0.03$ & $9811 \pm 1400$ & 85.85 \\
\hline BF12 & $10.74 \pm 0.09$ & $1.59 \pm 0.17$ & $0.90 \pm 0.08$ & $3.34 \pm 0.13$ & $3.30 \pm 0.02$ & $10300 \pm 1570$ & 80.68 \\
\hline BF15 & $20.77 \pm 0.08$ & $3.11 \pm 0.34$ & $0.92 \pm 0.10$ & $4.51 \pm 0.08$ & $3.08 \pm 0.01$ & $21972 \pm 1552$ & 70.93 \\
\hline BF18 & $20.75 \pm 0.04$ & $2.70 \pm 0.13$ & $1.61 \pm 0.12$ & $1.76 \pm 0.11$ & $2.47 \pm 0.01$ & $9663 \pm 1290$ & 61.03 \\
\hline BF21 & $10.23 \pm 0.04$ & $0.61 \pm 0.12$ & $0.85 \pm 0.09$ & $2.81 \pm 0.14$ & $6.95 \pm 0.02$ & $2449 \pm 886$ & 94.11 \\
\hline BF24 & $13.80 \pm 0.06$ & $2.24 \pm 0.26$ & $1.60 \pm 0.09$ & $3.38 \pm 0.12$ & $3.09 \pm 0.01$ & $15387 \pm 1574$ & 74.28 \\
\hline BF27 & $10.10 \pm 0.05$ & $0.94 \pm 0.17$ & $0.77 \pm 0.07$ & $5.21 \pm 0.11$ & $4.87 \pm 0.01$ & $1926 \pm 681$ & 91.47 \\
\hline BF30 & $8.69 \pm 0.05$ & $0.56 \pm 0.12$ & $1.10 \pm 0.09$ & $1.91 \pm 0.17$ & $6.53 \pm 0.02$ & $2079 \pm 703$ & 93.77 \\
\hline BF33 & $18.20 \pm 0.07$ & $4.65 \pm 0.29$ & $0.97 \pm 0.09$ & $2.78 \pm 0.09$ & $2.97 \pm 0.01$ & $8780 \pm 843$ & 55.28 \\
\hline BF36 & $18.93 \pm 0.06$ & $3.15 \pm 0.28$ & $0.87 \pm 0.09$ & $3.03 \pm 0.10$ & $4.67 \pm 0.01$ & $13196 \pm 1159$ & 70.96 \\
\hline BF39 & $20.63 \pm 0.05$ & $1.72 \pm 0.19$ & $1.26 \pm 0.09$ & $3.79 \pm 0.12$ & $5.57 \pm 0.01$ & $14905 \pm 1537$ & 84.47 \\
\hline BF42 & $8.92 \pm 0.04$ & $1.12 \pm 0.15$ & $1.23 \pm 0.09$ & $3.57 \pm 0.11$ & $5.12 \pm 0.01$ & $7332 \pm 1230$ & 88.58 \\
\hline BF45 & $10.10 \pm 0.05$ & $0.53 \pm 0.12$ & $0.87 \pm 0.09$ & $5.39 \pm 0.13$ & $4.88 \pm 0.01$ & $4276 \pm 548$ & 95.09 \\
\hline BF48 & $10.59 \pm 0.5$ & $1.05 \pm 0.17$ & $1.10 \pm 0.11$ & $4.38 \pm 0.11$ & $2.52 \pm 0.01$ & $4262 \pm 581$ & 86.79 \\
\hline BF51 & $23.10 \pm 0.06$ & $0.50 \pm 0.15$ & $0.45 \pm 0.05$ & $3.26 \pm 0.13$ & $6.83 \pm 0.02$ & $1810 \pm 647$ & 95.27 \\
\hline BF54 & $12.61 \pm 0.07$ & $0.70 \pm 0.16$ & $0.65 \pm 0.08$ & $5.33 \pm 0.14$ & $6.38 \pm 0.02$ & $2721 \pm 453$ & 94.35 \\
\hline BF57 & $12.41 \pm 0.05$ & $0.56 \pm 0.17$ & $0.46 \pm 0.07$ & $6.14 \pm 0.18$ & $4.80 \pm 0.20$ & $1458 \pm 495$ & 95.13 \\
\hline BF60 & $3.10 \pm 0.02$ & $0.45 \pm 0.10$ & $0.36 \pm 0.04$ & $6.34 \pm 0.02$ & $4.55 \pm 0.02$ & $1040 \pm 487$ & 96.03 \\
\hline BF63 & $10.21 \pm 0.04$ & $0.60 \pm 0.10$ & $0.32 \pm 0.05$ & $5.98 \pm 0.20$ & $4.18 \pm 0.02$ & $<500>$ & 94.42 \\
\hline BF66 & $1.14 \pm 0.10$ & $0.82 \pm 0.18$ & $0.26 \pm 0.05$ & $5.92 \pm 0.13$ & $4.21 \pm 0.01$ & $3040 \pm 568$ & 92.51 \\
\hline BF69 & $23.66 \pm 0.01$ & $1.00 \pm 0.27$ & $0.22 \pm 0.02$ & $6.93 \pm 0.23$ & $5.10 \pm 0.02$ & $3413 \pm 674$ & 92.32 \\
\hline BF72 & $6.27 \pm 0.32$ & $0.67 \pm 0.17$ & $0.21 \pm 0.03$ & $5.17 \pm 0.13$ & $3.65 \pm 0.01$ & $1134 \pm 380$ & 92.93 \\
\hline
\end{tabular}


Table 2. Elemental concentrations in ppm.

\begin{tabular}{|c|c|c|c|c|c|c|c|c|c|c|}
\hline Sample Code & $\mathbf{B a}$ & Co & $\mathrm{Cr}$ & Cs & $\mathbf{C u}$ & $\mathbf{L a}$ & Mn & Sc & $\mathbf{U}$ & $\mathbf{V}$ \\
\hline BF9 & $<4.30>$ & $21.21 \pm 2.55$ & $19.22 \pm 6.69$ & $5.09 \pm 1.64$ & $281 \pm 8$ & $116 \pm 12$ & $2600 \pm 300$ & $20.63 \pm 0.68$ & $<0.05>$ & $123 \pm 8$ \\
\hline BF12 & $124 \pm 44$ & $17.34 \pm 3.65$ & $<0.50>$ & $3.74 \pm 1.12$ & $183 \pm 9$ & $78.51 \pm 10.32$ & $1892 \pm 163$ & $16.42 \pm 0.64$ & $<0.05>$ & $108 \pm 7$ \\
\hline BF15 & $<4.30>$ & $13.65 \pm 4.25$ & $<0.50>$ & $1.85 \pm 0.15$ & $136 \pm 5$ & $87.34 \pm 8.21$ & $5965 \pm 340$ & $17.50 \pm 0.68$ & $<0.05>$ & $244 \pm 7$ \\
\hline BF18 & $114 \pm 32$ & $44.04 \pm 4.69$ & $<0.50>$ & $4.36 \pm 1.68$ & $128 \pm 9$ & $48.75 \pm 6.41$ & $1438 \pm 190$ & $44.66 \pm 1.10$ & $6.88 \pm 1.22$ & $95 \pm 6$ \\
\hline BF21 & $162 \pm 66$ & $13.5 \pm 2.91$ & $160 \pm 15$ & $<0.01>$ & $288 \pm 8$ & $61.25 \pm 8.63$ & $1162 \pm 191$ & $13.35 \pm 0.58$ & $4.39 \pm 1.64$ & $35 \pm 4$ \\
\hline BF24 & $<4.30>$ & $31.11 \pm 3.31$ & $124 \pm 12$ & $<0.01>$ & $128 \pm 4$ & $51.41 \pm 6.83$ & $2592 \pm 186$ & $39.98 \pm 0.63$ & $<0.05>$ & $92 \pm 8$ \\
\hline BF27 & $<4.30>$ & $16.87 \pm 3.70$ & $<0.50>$ & $4.30 \pm 0.88$ & $204 \pm 6$ & $122 \pm 10$ & $1189 \pm 207$ & $10.96 \pm 0.49$ & $<0.05>$ & $33 \pm 9$ \\
\hline BF30 & $104 \pm 24$ & $13.81 \pm 2.64$ & $99.63 \pm 9.19$ & $4.11 \pm 1.37$ & $314 \pm 10$ & $108 \pm 10$ & $936 \pm 80$ & $11.87 \pm 0.53$ & $<0.05>$ & $20 \pm 4$ \\
\hline BF33 & $151 \pm 60$ & $10.80 \pm 1.98$ & $96.56 \pm 11.23$ & $3.14 \pm 0.89$ & $140 \pm 6$ & $42.46 \pm 7.52$ & $6015 \pm 321$ & $12.91 \pm 0.61$ & $<0.05>$ & $157 \pm 9$ \\
\hline BF36 & $<4.30>$ & $5.88 \pm 0.99$ & $95.49 \pm 17.62$ & $2.17 \pm 0.79$ & $220 \pm 7$ & $97.33 \pm 10.59$ & $4748 \pm 242$ & $14.90 \pm 0.69$ & $<0.05>$ & $125 \pm 8$ \\
\hline BF39 & $<4.30>$ & $19.05 \pm 3.53$ & $<0.50>$ & $10.48 \pm 1.83$ & $221 \pm 7$ & $109.73 \pm 12.33$ & $3783 \pm 237$ & $18.89 \pm 0.65$ & $<0.05>$ & $113 \pm 8$ \\
\hline BF42 & $100 \pm 28$ & $24.10 \pm 3.10$ & $<0.50>$ & $1.51 \pm 0.27$ & $216 \pm 6$ & $112.13 \pm 12.34$ & $1898 \pm 178$ & $24.19 \pm 0.72$ & $2.33 \pm 0.33$ & $68 \pm 6$ \\
\hline BF45 & $<4.30>$ & $11.43 \pm 2.14$ & $<0.50>$ & $5.69 \pm 1.26$ & $200 \pm 7$ & $135 \pm 12$ & $1393 \pm 184$ & $14.62 \pm 0.57$ & $4.04 \pm 0.63$ & $36 \pm 5$ \\
\hline BF48 & $<4.30>$ & $17.77 \pm 2.88$ & $150 \pm 50$ & $5.25 \pm 1.91$ & $120 \pm 5$ & $130 \pm 14$ & $1811 \pm 192$ & $13.76 \pm 0.66$ & $5.92 \pm 0.56$ & $46 \pm 5$ \\
\hline BF51 & $<4.30>$ & $11.10 \pm 2.92$ & $254 \pm 86$ & $4.46 \pm 1.72$ & $287 \pm 9$ & $75.93 \pm 11.93$ & $910 \pm 227$ & $5.41 \pm 0.44$ & $5.18 \pm 0.43$ & $17 \pm 5$ \\
\hline BF54 & $<4.30>$ & $10.54 \pm 2.31$ & $37.36 \pm 7.25$ & $6.30 \pm 1.34$ & $174 \pm 7$ & $160 \pm 12$ & $1120 \pm 219$ & $6.33 \pm 0.44$ & $<0.05>$ & $23 \pm 5$ \\
\hline BF57 & $<4.30>$ & $<0.02>$ & $59.42 \pm 6.35$ & $3.95 \pm 1.17$ & $211 \pm 12$ & $161 \pm 11$ & $800 \pm 213$ & $2.69 \pm 0.42$ & $1.51 \pm 0.58$ & $<10.00>$ \\
\hline BF60 & $<4.30>$ & $11.53 \pm 3.34$ & $28.35 \pm 0.85$ & $1.10 \pm 0.47$ & $215 \pm 10$ & $138 \pm 10$ & $598 \pm 174$ & $3.19 \pm 0.30$ & $6.59 \pm 1.38$ & $10.87 \pm 4.32$ \\
\hline BF63 & $117 \pm 41$ & $2.56 \pm 0.44$ & $<0.50>$ & $4.42 \pm 1.07$ & $200 \pm 9$ & $132 \pm 10$ & $573 \pm 179$ & $4.37 \pm 0.36$ & $3.59 \pm 0.55$ & $<10.00>$ \\
\hline BF66 & $<4.30>$ & $5.17 \pm 1.64$ & $<0.50>$ & $3.19 \pm 1.07$ & $180 \pm 7$ & $123 \pm 11$ & $928 \pm 213$ & $4.26 \pm 0.32$ & $9.28 \pm 4.25$ & $12.45 \pm 3.67$ \\
\hline BF69 & $<4.30>$ & $6.10 \pm 2.43$ & $<0.50>$ & $2.21 \pm 0.24$ & $213 \pm 10$ & $209 \pm 11$ & $1685 \pm 243$ & $3.94 \pm 0.33$ & $8.50 \pm 2.80$ & $14.76 \pm 4.31$ \\
\hline BF72 & $<4.30>$ & $6.88 \pm 2.33$ & $34.65 \pm 5.93$ & $2.10 \pm 0.28$ & $156 \pm 6$ & $112 \pm 12$ & $384 \pm 98$ & $3.77 \pm 0.31$ & $2.87 \pm 0.42$ & $454 \pm 1.30$ \\
\hline
\end{tabular}

Felsic index of each of the samples was computed and this is captured on Table 1. The average felsic index (F) calculated for all the sample is: 85.74. This implies that the rocks of the contact are generally felsic and less mafic. The comparatively high content of oxides of sodium and aluminum and the felsic index indicate that the rocks are feldspar rich [7]. The relatively high content of potassium-aluminum oxides as compared to calciumaluminum oxides indicates that orthoclase (K-) feldspars are the dominants feldspars. Iron and titanium oxides got depleted with depths from the $52 \mathrm{~m}$ below surface downward while potassium oxide is enriched from $42 \mathrm{~m}$ depth below surface downward. Concentrations of the other major oxides varied at different depths though not in trend as could be seen from Table 1.

From Table 1 concentrations of $\mathrm{K}_{2} \mathrm{O}$ are comparatively higher in the Dahomeyan segment of the borehole than in the Togo segment of the borehole indicating that the Dahomeyan rocks are K-feldspar richer than the Togo rocks, though; both rock types are generally feldspar rich. This shows that the Dahomeyan formations are a higher grade metamorphic rocks which were formed under higher temperatures and pressures. The Togo rocks on the other hand, have higher iron content as compared to the Dahomeyan; and therefore abound in iron minerals such as biotite and hornblende which are predominant minerals in the Togo schist, quartzite and phyllite; the main rock types of the Togo formations [8]. Biotite schist crystallizes from a relative lower temperatures therefore it can be established that the Togo formations were formed under relatively lower temperatures therefore the two terranes - the Togo rocks and the Dahomeyan rocks were formed under different geothermal conditions with the Dahomeyan being formed under higher geothermal gradient.

Elemental occurrences varied in the Togo rocks and 


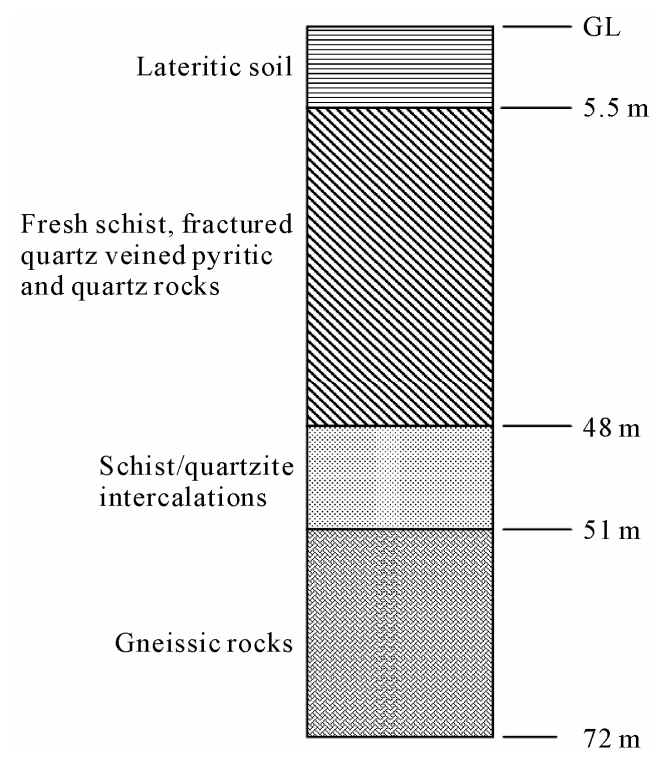

Figure 2. Lithostratigraphic profile of the borehole as per examination of drilled cuttings.

the Dahomeyan rocks show the clear mineralogical distinction between the two types of geologic terranes [9]. For instance, uranium occurrence in the Dahomeyan was within detectable limits in all the lithostratigraphic levels studied in exception of BF54 as against the Togo rocks were uranium content was below detection limit in many of the lithostratigraphic units. The Togo rocks had higher scandium concentrations than the Dahomeyan rocks. This however, is attributable to the fact that though scandium is widely dispersed in most minerals of the crust, aluminum substitution with scandium could give rise to elevated scandium concentrations in rocks/minerals with high aluminum content. The thrust contact is well depicted in the values of elemental concentrations (see Table 1). The contact occurred at $48 \mathrm{~m}$ below surface level up to around $51 \mathrm{~m}$.

\section{CONCLUSIONS}

This work has revealed the elemental and mineralogical compositions of rocks of the various lithostratigrphic units of the famous Togo-Dahomeyan contact at Kwae- benya near Accra. The results have been useful in the prediction of origin and evolution of the Togo-Dahomeyan contact. The rocks are felsic having average felsic index (F) of 85.74. They are feldspar rich with K- (orthoclase) feldspars dominating. Iron and titanium oxides are depleted with depths from $52 \mathrm{~m}$ below surface level downward in the borehole, and potassium oxide is enriched from $42 \mathrm{~m}$ depth below surface level downward in the borehole. The Togo and the Dahomeyan rocks had different concentrations of the major elements and oxides assayed as shown on Table $\mathbf{1}$.

\section{ACKNOWLEDGEMENTS}

The authors acknowledge the sponsor of the drilled borehole: The Ghana Atomic Energy Commission and the contributions of staff of the Ghana Research Reactor-1 (GHARR-1) centre in sample irradiation and counting.

\section{REFERENCES}

[1] Blay, P.K. (1982) Geology of 1/4 Field Sheets 184, 185 and 187. Ghana Geological Survey Bulletin, 45.

[2] Kesse, G.O. (1985) The mineral and rock resources of Ghana, Balkema, Rotterdam, 32-41.

[3] Wright, J.B. (1985) Geology and mineral resources of West Africa. Science, 58-59.

[4] Mani, R. (1978) The geology of the Dahomeyan of Ghana. Geology of Ghana Project. Ghana Geological Survey Bulletin, 45.

[5] Efa, E. and Muff, R. (2003-2005) Ghana Geological Survey Department, Field Mapping.

[6] ORTEC (2002) Advanced measurement technology, Incorporated Part, 777800.

[7] Amili, R. (1977) Internal structure and mineralogy of the Gloserheia granite pegmatite, Froland, Southern Norway. Norsk Geologisk Tidsskrift, 57, 243-262.

[8] Nude, P.M., Shervais, J.W., Attoh, K., Vetter, S.K. and Barton, C. (2009) Petrology and geochemistry of nepheline syenite and related carbonate-rich rocks in the Pan-African Dahomeyan orogen, southern Ghana West Africa. Journal of African Earth Sciences, 55, 147-157. doi:10.1016/j.jafrearsci.2009.03.010

[9] Muff, R. and Efa, E. (2006) Environmental and Engineering Geology for Urban Planning in Accra-Tema. Ghana Geological Survey Department Bulletin, 55. 